\title{
KEMATANGAN SOSIAL PADA REMAJA DI PANTI ASUHAN FAHMI MAKASSAR
}

\author{
Novita Ashari \\ Institut Agama Islam Negeri Parepare, Indonesia \\ novitaashari@iainpare.ac.id
}

Received: 08-10-2020

Revised: 14-12-2020

Accepted: 02-01-2021

\section{Social Death in Adolescents at Fahmi Makassar Orphanage}

\begin{abstract}
This study aims to see how the social maturity of adolescents at the Fahmi Orphanage Makassar. The research will use qualitative research methods. Qualitative research is the stage of the research approach and understanding that is sourced from the method of phenomena that occur in social life as well as problems between individuals. The subjects in this study were adolescents, both boys, and girls who were at the Fahmi Orphanage in Makassar. The results of this study are the social maturity of adolescents at the Fabmi Orphanage known by their family background. Adolescents who come from intact families who have high self-confidence so that their social maturity is also good. Meanwhile, adolescents who come from families who have low self-confidence so that their social maturity is not good.
\end{abstract}

Keywords: adolescents, social maturity, orphanage

\begin{abstract}
Abstrak
Penelitian ini bertujuan untuk mengetahui bagaimana kematangan sosial pada remaja yang berada di Panti Asuhan Fahmi Makassar. Penelitian yang akan digunakan metode penelitian kualitatif. Penelitian kualitatif merupakan tahapan pendekatan penelitian dan pemahaman yang yang bersumber pada metode yang fenomena yang terjadi pada kehidupan sosial serta permasalahan antar individu. Subjek dalam penelitian ini adalah remaja baik itu laki-laki maupun perempuan yang berada di Panti Asuhan Fahmi di Makassar. Hasil penelitian ini adalah kematangan sosial pada remaja di Panti Asuhan Fahmi dipengaruhi oleh latar belakang keluarganya. Remaja yang berasal dari keluarga yang utuh mempunyai rasa percaya diri yang tinggi sehingga kematangan sosialnya juga baik. Sedangkan remaja yang berasal dari keluarga broken home mempunyai rasa percaya diri yang rendah sehingga kematangan sosialnya pun tidak baik.
\end{abstract}

Kata Kunci : remaja, kematangan sosial, panti asuhan

\section{PENDAHULUAN}

Masa remaja merupakan masa yang asam manis, kadang menyenangkan kadang pula menyulitkan dan kritis karena merupakan masa transisi dari anak-anak menuju dewasa. Seorang anak belum selesai perkembangannya, sehingga dengan jelas masa anak-anak berbeda dengan masa dewasa dan orang tua. Masa dewa boleh dikatakan sudah selesai perkembangannya sedangkan masa tua pada umumnya terjadi kemunduran utamanya pada fungsi fisik ${ }^{1}$.

1 S.R. Monks, F.J., Knoers, A.M.P., \& Haditono, Psikologi Perkembangan: Pengantar Dalam Berbagai Bagiannya (Yogyakarta: Gajah Mada University Press, 2006). 
Remaja adalah salah satu fase yang harus dilalui oleh inidividu. Masa remaja meruipakan masa transisi dari masa anak-anak menuju masa dewasa. Remaja memiliki tugas perkembangan yang harus tercapai, diantaranya, yaitu: (1) penerimaan diri yang positif dan melaksanakan perannya berdasarkan gender; (2) bisa bersosialisasi dengan teman baik yang berjenis kelamin sama maupun teman yang jenis kelamin berbeda; (3) bisa menciptakan emosional personal terhadap orang dewasa disekitarnya; (4) bisa menciptakan jaminan kemandirian finansial, (5) bisa menentukan dan merencanakan pekerjaan; (6) bisa membangun skill intelektual dan suatu pemikiran yang dibutuhkan dalam kompetensi sebagai warga negara; (7) bisa bertanggung jawab secara sosial; (8) bisa merencanakan pernikahan dan kehidupan berumah tangga, dan (9) bisa menjalankan nila-nilai yang ada berdasarkan norma yang berlaku ${ }^{2}$.

Stanley Hall mengemukakan bahwa pada saat melewati masa remaja, pemuasan terhadap kebutuhan jiwa, raga dan social sangat diperlukan bagi perkembangannya. Pada masa remaja juga dikenal masa topan badai dan stress. Remaja merasa memiliki penuh terhadap dirinya senidiri untuk menentukan nasibnya, jika memiliki arah yang benar maka akan menjadi pribadi yang bertanggung jawab, namun jika tidak terarah maka bisa menjadi individu yang memiliki masa depan yang kurang baik ${ }^{3}$.

Perubahan-perubahan yang terjadi dalam diri remaja di masa pubertasnya sangat membutuhkan peranan keluarga. Keluarga merupakan tempat dimana remaja dirawat dan dibesarkan dalam kehidupan berkeluarga dimana kedua orang tuanya masih hadir sebagai pengasuh utama. Dalam keseharian seorang remaja selalu membutuhkan rasa dikasihi dan rasa bahwa remaja tersebut diakui keberadaannya dalam suatu keluarga. Berdasarkan hasil penelitian Bowlby menunjukkan bahwa kehidupan seorang anak yang sehat secara jiwa, raga, dan sosial membutuhkan suatu hubungan yang harmonis yang mengandung tiga hal utama, yaitu: (1) relasi ibu dan anak, (2) relasi anak dan keluarga, (3) relasi anak dan lingkungan sosialnya ${ }^{4}$.

Kecakapan remaja bersosialisasi dengan lingkungan akan berdampak pada kehidupan sosialnya di masa yang akan datang. Interaksi sosial merupakan interaksi antara dua orang manusia atau lebih yang saling memerlukan satu sama lain. Interaksi sosial diawali dengan tahapan yang bersifat sederhana yang dilandasi dengan keinginan yang sederhana pula. Semakin bertambah usia, keinginan manusia pun menjadi semakin bertambah, oleh karenanya tahapan interaksi sosialpun menjadi semakin bertambah rumit. Anwar menambahkan bahwa dalam bersosialisasi, individu akan berada pada tahap pengenalan dan melakukan adaptasi kepada situasi dan kondisi pada keadaan lingkungan tempat tinggalnya ${ }^{5}$.

Kematangan sosial adalah suatu perubahan perkembangan perilaku, dimana pada akhirnya individu mampu menunjukkan pengalaman yang dimiliki secara lengkap dan individu tersebut mampu belajar step by step dalam menambah kompetensi dalam hidup independen,

2 I. Ramanda, P. \& Khairat, "Perbedaan Kematangan Sosial Siswa Yang Berasal Dari Sekolah Homogen Dan Sekolah Heterogen," Jurnal Kajian Bimbingan Dan Konseling 2, no. 4 (2017): 148-156.

3 John W Santrock, Perkembangan Remaja (11th Ed.), Perkembangan Remaja (11th Ed.), 2007.

${ }^{4}$ Monks, F.J., Knoers, A.M.P., \& Haditono, Psikologi Perkembangan: Pengantar Dalam Berbagai Bagiannya.

5 Anwar Anwar, "Paradigma Sosialisasi Dan Kontribusinya Terhadap Pengembangan Jiwa Beragama Anak," KOMUNIDA: MEDIA KOMUNIKASI DAN DAKWAH, 2018, https://doi.org/10.35905/komunida.v8i2.631. 
nengadakan hubungan kerjasama dan memiliki rasa tanggung jawab baik untuk diri sendiri maupun golongan ${ }^{6}$. Doll menambahkan bawah kapasitas seseorang dalam mengelolah dirinya sendiri dan ikut berperan serta dalam aktivitas yang mengarahkan pada kehidupan yang independen ${ }^{7}$.

Kematangan sosial adalah suatu kapasitas yang mampu membantu seseorang agar bisa bertingkah laku berdasarkan desakan lingkungan sosialnya. Kematangan sosial juga mampu mempermudah seseorang dalam pemenuhan tugas perkembangannya. Seseorang yang memiliki kematangan sosial baik adalah seseorang yang tidak bergantung pada orang lain dalam mengerjakan kegiatannya sehari-hari, mampu menyesuaikan diri dan berbaur dengan baik serta mampu mengontrol segala bentuk emosi yang dirasakan. Kematangan sosial merupakan cara perpaduan antara intrapersonal, interpersonal dan sosial seseorang agar mampu berkelakuan secara tepat di lingkungan masyarakat ${ }^{8}$.

Kematangan sosial yang baik secara langsung maupun tidak bisa menolong seseorang dalam berbaur sesuai dengan norma yang ada di lingkungannya atau menolong seseorang untuk bisa tetap survive dalam kehidupannya dalam segala bentuk keadaan dan kondisi yang ada. Jika seseorang mampu beradaptasi dengan kehidupan sosialnya maka ia akan merasa berharga dan merasa dibutuhkan oleh lingkungannya. Kematangan sosial meningkatkan kepercayaan diri pada seseorang ${ }^{9}$.

Remaja yang memiliki kemahiran dalam bersosialisasi dengan keadaan sekitar sehingga terbentuk kebiasaan baru pada kehidupan sosialnya, hal tersebut menunjukkan bahwa seorang remaja memiliki kematangan sosial yang baik ${ }^{10}$. Porvaznik mengemukakan bahwa seseorang dengan kematangan sosial yang baik akan mudah menyelesaikan permasalahan yang dihadapi ${ }^{11}$. Inividu akan lebih mudah mngelolah emosinya dan memikirkan secara matang sebelum melakukan sesuatu. Kematangan sosial akan membuat individu mampu mengembangkan potensinya di dunia luar dan membuat individu tidak mudah bergantung kepada orang lain ${ }^{12}$.

Remaja yang kematangan sosialnya baik akan lebih mudah paham terhadap kepentingan orang disekitarnya dan mengetahui seberapa penting kepentingan tersebut. Remaja akan lebih empati bahwasanya kebahagiaan diri berkaitan erat dengan kebahagiaan orang lain, sehingga

6 U. Pratiwi, L. Lusmilasari, and S. Hartini, "Hubungan Antara Kematangan Sosial Dengan Kemandirian Pemenuhan Aktivitas Dasar Penyandang Retardasi Mental," Jurnal Ilmu Keperawatan UGM, 2008.

7 Adinni Vibrananda Lisardika and Heru Astikasari Setya Murti, "Perbedaan Kematangan Sosial Anak Usia Dini Ditinjau Dari Keikutsertaan Di Taman Penitipan Anak (TPA)," Psikologika: Jurnal Pemikiran Dan Penelitian Psikologi, 2017, https://doi.org/10.20885/psikologika.vol22.iss2.art7.

${ }^{8}$ C. Marcelyna, "Studi Kasus Karakteristik Kematangan SosialPada Anak Cerebral PalsyDitinjau Dari VSMS(Vineland Social Maturity Scale)," Ristekdik (Jurnal Bimbingan Dan Konseling) 5, no. 2 (2020): 146-54.

${ }_{9}^{9}$ E.A. Ghofiniyah, E. \& Setiowati, "Hubungan Antara Kematangan Emosi Dan Keterampilan Sosial Dengan Penyesuaian Diri Pada Santri Pondok Pesantren Daar Al Furqon Kudus," Proyeksi 12, no. 1 (2017): 116.

10 Sri Widyawati and Martha Kurnia Asih, "KEMATANGAN SOSIAL DITINJAU DARI KOMUNIKASI DIADIK IBU DAN ANAK PADA PESERTA DIDIK TK/PAUD,” Jurnal Dinamika Sosial Budaya, 2017, https://doi.org/10.26623/jdsb.v18i2.578.

11 Qudsi Iftikar Wahyudhi, Tulus Winarsunu, and Sofa Amalia, "Kematangan Sosial Dan Problem Focused Coping Pada Laki-Laki Usia Dewasa Awal," Jurnal Ilmiah Psikologi Terapan, 2019, https://doi.org/10.22219/jipt.v7i1.7835.

12 Widyawati and Asih, "KEMATANGAN SOSIAL DITINJAU DARI KOMUNIKASI DIADIK IBU DAN ANAK PADA PESERTA DIDIK TK/PAUD.” 
perasaan dendam, benci, dengki, marah dan iri akan lebih mudah dikendalikan. Perilaku tersebut menjadikan remaja dapat menjalin persahabatan dan ikatan pertemanan dengan orang lain $^{13}$.

Individu menunjukkan kematangan sosial ketika individu tersebut mampu membuka diri terhadap kehadiran orang lain tanpa harus mengkitik atau mengatur orang lain agar menjadi sesuai dengan apa yang diinginkannya. Kematangan sosial juga terlihat pada pandangan sosialnya yang menjadikan individu mampu menaksirkan dan mampu beradaptasi dengan sigap dengan orang lain dengan situasi sosial yang berbeda-beda ${ }^{14}$. Doll menambahkan bahwa kematangan individu akan mudah nampak dari tingkah lakunya. Tingkah laku tersebut mengungkapkan kapasitas seseorang dalam melakukan manajemen terhadap tubuhnya dan berperan serta dalam kegiatan-kegiatan yang menuju pada kemampuan otonom selayaknya manusia dewasa ${ }^{15}$.

Panti Asuhan merupakan suatu tempat yang mampu memberikan wadah kepada seorang remaja untuk mewujudkan kesejahteraan sosial. Anak yang berada di panti asuhan adalah anak yang sudah tidak mempunyai keluarga atau bisa juga disebabkan oleh orang tua yang meninggal dunia atau sudah berpisah ${ }^{16}$. Pengurus Panti Asuhan Fahmi, Drs. A. Abd. Rahman Mahdi menjelaskan bahwa banyak orang yang salah menafsirkan panti asuhan. Pada umumnya yang diketahui oleh masyarakat panti asuhan hanya untuk anak yatim piyatu, padahal panti asuhan juga untuk mereka yang mengalami broken bome, dibuang oleh keluarganya, anak-anak terlantar, dan lain-lain.

Secara umum anak yang berada di Panti adalah anak yang memerlukan kasih dan saying dari orang tua, sehingga sering dijumpai anak yang terkadang rewel, suka mencuri-curi perhatian orang dewasa dengan memperlihatkan tingkah laku agar bisa menarik simpati dari para pengurus yang berada di Panti Asuhan Fahmi. Tingkah laku anak yang tinggal di Panti Asuhan Fahmi Makassar memiliki berbagai macam model mulai dari yang anak-anak hingga dewasa. berbagai jenis perilaku yang mereka tunjukkan dalam melampiaskan emosinya. Sehingga mereka membutuhkan pendampingan dari para pengurus panti agar bisa memiliki budi pekerti yang baik ${ }^{17}$.

Panti asuhan memang memiliki tujuan positif bagi remaja yang tidak memiliki sanak saudara atau tidak mampu diasuh oleh keluarganya. Namun, panti asuhan memiliki dampak yang buruk bagi perkembangan anak, dimana anak tersebut tidak mampu mendapatkan sosok keluarga yang secara keseluruhan bisa menggantikan fungsi keluarga yaitu: terciptanya anak

13 R. Furqona, "Hubungan Antara Kesadaran Beragama Dan Kematangan Sosial Dengan Agresivitas Remaja (Santri) Pondok Pesantren Modern Islam Assalaam Surakarta," Jurnal Ilmiah Psikologi Pendidikan Dan Perkembangan 1, no. 1 (2009): 51-62.

${ }^{14}$ Hurlock Elisabet, Psikologi Perkembangan Suatu Pendekatan Sepanjang Rentang Hidup., Erlangga, 2010.

15 A. Hartanti, "Perbedaan Tingkat Kematangan Sosial Anak Berdasarkan Urutan Kelahiran Pada Siswa TK Islam Terpadu Kelas B Mutiara Hati Sawojajar Malang” (Universitas Islam Negeri Maulana Malik Ibrahim Malang, 2010).

16 S.W. Maibang, "Peran Panti Asuhan Putri 'Aisyiyah Dalam Mengembangkan Kreativitas Anak" (Universitas Asislam Negeri Sumatera Utara, 2017).

17 Magdalena, Hasan Almutahar, and Antonia Sasap Abao, "Pola Pengasuhan Anak Yatim Terlantar Dan Kurang Mampu Di Panti Asuhan Bunda Pengharapan (PABP) Di Kecamatan Sungai Raya Kabupaten Kubu Raya," Jurnal PMIS-Utab, 2014. 
yang tertutup, pasif apatis, tidak percaya diri, gampang berputus asa, mudah takut dan cemas , sehingga akan sulit bersosialisasi dengan orang di sekitarnya ${ }^{18}$.

Lingkungan dimana seorang remaja tumbuh dan berkembang yang diberikan perhatian dan dukungan penuh akan turut memberi sumbangsih tersendiri di dalam dirinya, termasuk bagaimana anak membangun konsep dalam dirinya. Lingkungan merupakan variable external yang mampu meberikan sumbangsih tersendiri dalam hal pembelajaran dan pengalaman yang diperlukan $^{19}$. Ketika anak disebasarkan dengan pengasuh dan lingkungan yang baik maka akan mampu menumbuhkan segala potensi dalam diri anak berkembangan karena memiliki kesempatan untuk mengembangkan kemampuan yang dimilikinya. Lingkungan akan sangat mempengaruhi perkembangan anak.

Remaja yang berkembang di lingkungan panti asuhan akan menemukan banyak aturan dan tata tertib dari pemiliki yayasan. Aturan yang lebih dikenal sebagai tata tertib ini merupakan orbit yang harus dilakukan. Hal tersebut akhirnya menjadikan sulit dalam beradaptasi dengan aturan yang telah ada dan merasa terikat, sehingga yang ada remaja akan sering melanggar aturan yang telah ada.

Margareth mengemukakan dalam penelitiannya bahwa kehidupan anak di panti asuhan sangat tidak efisien karena anak akan dperlakukan sebagai makhluk biologis bukan makhlus yang memiliki psikis dan kehidupan sosial. Dimana seharusnya bukan hanya kebutuhan biologis yang diperhatikan, anak juga menginginkan kasih sayang untuk mental yang sehat ${ }^{20}$.

\section{METODE PENELITIAN}

Penelitian yang akan digunakan metode penelitian kualitatif. Penelitian kualitatif merupakan tahapan pendekatan penelitian dan pemahaman yang yang bersumber pada metode yang fenomena yang terjadi pada kehidupan sosial serta permasalahan antar individu.. metodologi ini, peneliti akan merancang suatu gambaran lengkap, mendeskripsikan, laporan terinci dari pandangan responden, dan melakukan studi pada keadaan yang sebenarnya terjadi ${ }^{21}$.

Kirk \& Miller mengemukakan bahwa penelitian kualitatif awalnya berpusat pada observasi kualitatif yang dipermasalahkan dengan observasi kuantitatif. Kemudia mereka menjelaskan bahwa metodologi kualitatif adalah suatu budaya pada bagian ilmu pengetahuan sosial yang krusial sangat berkaitan dengan manusia dan kehidupannya sendiri serta berkaitan dengan manusia serta bahasa yang digunakan. Penelitian kualitatif memiliki keistimewaan tersendiri yang memisahkannya dengan jenis metodologi yang lain ${ }^{22}$.

\section{HASIL DAN DISKUSI DATA}

Secara umum ketiga subjek siswa dari SMA dan SMK yang berbeda, dimana ketiga subjek tersebut hanya memiliki perbedaan satu tahun jenjang pendidikan. Hasil penelitian yang diperoleh, ditemukan bahwa ketiga subjek tersebut merasal dari status ekonomi yang sama akan tetapi latar belakang keluarga mereka berbeda. AS dan AN sendiri walaupun mereka hidup dalam kesederhanaan, namun mereka masih memiliki keluarga yang lengkap (ayah

\footnotetext{
18 Elisabet, Psikologi Perkembangan Suatu Pendekatan Sepanjang Rentang Hidup.

19 Anwar, "Paradigma Sosialisasi Dan Kontribusinya Terhadap Pengembangan Jiwa Beragama Anak."

${ }^{20}$ Elisabet, Psikologi Perkembangan Suatu Pendekatan Sepanjang Rentang Hidup.

${ }^{21}$ John W. Creswell, Qualitative Inquiry and Research Design, Qualitative Inquiry and Research Design, 2013.

22 Pupu Saeful Rahmat, "Penelitian Kualitatif," Journal Equilibrium, 2009.
} 
ibunya masih bersama). Berbeda dengan subjek WA yan berasal dari keluarga broken home. Kedua orang tua WA telah bercerai ketika WA berusia 3 tahun.

Pekerjaan orang tua AN dan AS adalah petani yang memiliki penghasilan yang sedikit. Begitu pula dengan WA, hasil dari pekerjaan buruh bangunan ayahnya tidak begitu banyak. Sehingga sangat jelas terlihat bahwa alasan masing-masin subjek berada di panti karena kekurangan biaya dan ingin melanjutkan sekolah. Orang tua ketiga subjek tersebut tidak mampu membiayai pendidikan subjek. Jadi jika subjek tidak berada di panti, maka seubjek tidak dapat melanjutkan sekolahnya.

Asrori memaparkan bahwa salah satu komponen penting yang akan memberikan pengaruh kepada seorang remaja adalah bagaimana hubungan antar keluarga. Keharmonisan, intensitas dan kedekatan antar anggota keluarga akan berdampak terhadap perkembangan sosial remaja. Disamping itu, remaja juga membutuhkan panutan dalam kehidupannya karena masa remaja rentan terhadap pengaruh dari luar sehingga biasa juga disebut masa krisis identitas. Perwujudan dari panutan remaja tersebut akan diidentifikasi sehingga menjadikan orang tua sebagai pendengar yang pertama ${ }^{23}$.

AN dan AS tidak pernah mendapat kunjungan dari orang tuanya selama mereka berada di panti. Namun, AN dan AS masih memiliki komunikasi dengan orang tuanya kerena mereka biasanya akan pulang ke kampung masing-masing jika hari raya atau hari libur tiba. Berbeda dengan WA yang tidak pernah lagi berkomunikasi dengan orang tuanya. Semenjak perceraian tersebut ibu WA menghilang sedangkan ayahnya terkadang menjenguknya di panti namun mereka tidak pernah bertemu. Ketiga subjek tersebut tidak pernah mendapatkan nafkah berupa materi dari orang tuanya.

Masing-masing subjek berbeda dalam pergaulannya di sekolah. WA dan AS hanya memiliki teman dekat sedangkan AN memiliki teman dekat dan geng di sekolah. WA hanya memiliki seorang sahabat dan AS hanya memiliki dua orang sahabat di sekolah. WA dan AS sangat jarang menghabiskan waktu dengan teman-temanya seperti jalan-jalan, nonton, dan sebagainya. WA dan AS hanya keluar jika kepentingan tersebut berhubungan dengan sekolahnya. Lain halnya dengan AN, ia terkadang berbohong demi kepentingan gengnya. Walaupun berbeda dalam hal pertemanan, namun WA, AN, dan AS mengaku pernah mengalami ketertarikan dengan lawan jenisnya.

Hurlock menambahkan bahwa penyesuasian sosial merupakan salah satu tahap perkembangan yang sulit diselesaikan oleh seorang remaja. Remaja harus bisa beradaptasi. dengan segala bentuk relasi dari orang lain baik itu di lingkungan sekolah maupun di keluarga $^{24}$.

AS memiliki pengaruh kepemimpinan yang baik di sekolahnya. Berbeda dengan AN yang tidak pernah mendapatkan kepercayaan untuk menduduki jabatan bergengsi di sekolahnya. AS memegang jabatan sebagai bendahara OSIS. AS seharusnya menjabat sebagai wakil ketua OSIS, namun karena ia masih pemula di OSIS sehingga AS belum mendapatkan izin dari gurunya.

23 Mohammad Asrori, "Psikologi Remaja: Perkembangan Peserta Didik. Jakarta: PT Bumi Aksara. Hlm.," Psikologi Remaja Perkembangan Peserta Didik, 2017.

${ }^{24}$ Elisabet, Psikologi Perkembangan Suatu Pendekatan Sepanjang Rentang Hidup. 
Berdasarkan hasil penelitian Ramanda dan Khairat menjelaskan bahwa kemampuan remaja dalam kehidupan sosialnya yang penuh dengan tanggung jawab adalah bentuk kematangan sosial pada remaja ${ }^{25}$. Subjek AS terbukti mendapatkan kepercayaan karena mampu memegang jabatan sebagai bendahara OSIS di sekolah. Seseorang yang memegang suatu jabatan adalah orang yang dianggap bertanggung jawab oleh teman-temannya. Bahkan AS sebenarnya dipercaya sebagai wakil ketua OSIS, namun karena ia masih tergolong siswa baru untuk jabatan tinggi, maka gurunya tidak memberikan izin.

Sejalan dengan penelitian di atas, hasil penelitian selanjutnya menunjukkan bahwa remaja yang berada disuatu wadah seperti panti asuhan mau tidak mau harus berinteraksi dengan lebih dari satu orang baik dengan teman sebayanya maupun orang yang lebih tua dan muda. Sehingga, jika remaja tersebut tidak memiliki kematangan sosial yang baik maka akan terjadi beberapa hal, antara lain tidak tidak memiliki majamen waktu yang baik, tidak bisa mengendalikan diri, penerimaan diri dan orang lain yang buruk, tidak suka menolong, tidak mampu bersaing sehat dan selalu pesimis ${ }^{26}$. Hal tersebut sesuai dengan subjek WA yang tidak memiliki gank dan tidak terlibat dalam OSIS sekolah. WA adalah pribadi yang tertutup dengan lingkungannya.

Pengurus panti selalu memberikan lampu hijau kepada anak panti ketika ingin melakukan aktivitas di luar, tapi dengan catatan harus berhubungan dengan pendidikan. Pengurus panti tidak melarang anak pantinya mengikuti ekstrakulikuler di sekolah. Inti dari pengasuhan yang diterapkan adalah memberikan kebebasan kepada para anak panti namun tetap dalam pengawasan. Pengurus panti juga selalu memberikan motivasi dengan contoh yang nyata kepada anak-anak di panti. Hal tersebut dilakukan karena sebagian besar penghuni di panti adalah remaja sehingga ia mengajarkannya untuk lebih dewasa.

Remaja akan dianggap memiliki kematangan sosial yang baik jika ia mampu menunjukkan keberhasilan dalam bersosialisasi sehingga mampu berbaur dengan lingkungan sekitarnya $^{27}$. Hal tersebut dapat terlihat pada subjek AN, dimana ia masih memiliki genk di sekolahnya. AN menunjukkan bahwa walaupun ia berasal dari panti namun ia mampu bersosialisasi dengan linkungannya. AN dapat diterima dengan baik dalam kehidupan sosialnya.

Penjelasan di atas sejalan dengan hasil penelitian Ramanda dan Khairat. Penelitian tersebut menjelaskan bahwa seluruh organ seksual manusia akan matang di usia remaja. Pemahaman seorang remaja terhadap fungsi sosialnya serta kemampuan melakukannya sesuai dengan jenis kelaminnya. Kemampuan dalam melakukan peran sosial berdarkan jenis kelamin merupakan salah satu aspek yang menunjukkan kematangan sosial ${ }^{28}$.

${ }^{25}$ Ramanda, P. \& Khairat, "Perbedaan Kematangan Sosial Siswa Yang Berasal Dari Sekolah Homogen Dan Sekolah Heterogen."

${ }^{26}$ Furqona, "Hubungan Antara Kesadaran Beragama Dan Kematangan Sosial Dengan Agresivitas Remaja (Santri) Pondok Pesantren Modern Islam Assalaam Surakarta."

${ }^{27}$ S. Pratiwi, U., Lusmilasari, L. \& Hartini, "Hubungan Antara Kematangan Sosial Dengan Kemandirian Pemenuhan Aktivitas Dasar Penyandang Retardasi Mental," JIK 03, no. 03 (2008): 202-9.

${ }^{28}$ Ramanda, P. \& Khairat, "Perbedaan Kematangan Sosial Siswa Yang Berasal Dari Sekolah Homogen Dan Sekolah Heterogen." 
Hal tersebut sesuai dengan teori Hurlock yang mengatakan bahwa kemampuan individu dalam mencapai kematangan sosial dapat dilihat dengan mampunya individu tersebut dalam menyesuaikan diri dengan lingkungan sekitarnya, semakin baik tingkat kematangan sosialnya maka akan semakin baik pula kemampuannya menyesuaikan diri berdasarkan tekanan emosi yang dirasakan. Kemampuan remaja dalam bergabung pada suatu kelompok merupakan suatu bentuk kebutuhan dalam rangka meningkatkan ikatan sosial yang baik antar sesama ${ }^{29}$.

Kemampuan remaja dalam bertanggung jawab sesuai porsinya dan mampu mengamalkan segala bentuk norma serta aturan yang berlaku di lingkungannya merupakan definisi kematangan sosial.Remaja mampu merawat diri, berosialisasi dengan sehat serta memiliki rasa empati terhadap orang disekitarnya merupakan indikator kematangan sosial. Remaja yang memiliki kematangan sosial yang baik maka ia mampu mengontrol diri dan emosinya serta adanya kompetensi untuk menempatkan dirinya dengan baik dalam suatu kelompok sosial ${ }^{30}$. Berdasarkan teori tersebut, AN dan AS sudah mencerminkan kematangan sosial yang baik. AN dan AS mampu terlibat dalam kehidupan sosial dan tergabung dalam sebuah komunitas di lingkungannya.

Kematangan sosial pada remaja sangat dipengaruhi oleh latar belakang keluarganya. Oleh karena itu, pendamping anak-anak di panti asuhan harus betul-betul menggunakan perannya dalam keseharian anak. Anak di panti asuhan membutuhkan orang dewasa yang bisa berperan sebagai orang tua pengganti mereka. Oleh karena itu, peneliti berharap kepada peneliti selanjutnya untuk lebih menggali pola asuh yang yang ideal yang sebaiknya diterapkan di panti asuhan.

\section{KESIMPULAN}

Bersosialisasi intinya adalah suatu pada remaja dalam menyesuaikan diri lingkungan sosialnya dan dan remaja tersebut mampu berbaur dan turut serta dalam kelompoknya baik itu kelompok besar ataupun kelompok kecil. Hal tersebut terlihat pada subjek AS yang mampu terlibat dalam kelopok besar (OSIS) dan memegang jabatan dalam kelompok tersebut. Sementara AN terlibat dalam kelompok kecil, dimana AN tergabung dalam sebuah genk di kelasnya. Kedua subjek ini masih memiliki orang tua utuh yang hidup harmonis. Lain halnya dengan WA yang berasal dari keluarga broken home, WA tidak memiliki gank memiliki pergaulan yang berarti di sekolah. Ia cenderung menutup diri dari lingkungannya.

Kematangan sosial pada remaja yang berada di Panti Asuhan Fahmi dipengaruhi oleh latar belakang keluarganya. Remaja yang berasal dari keluarga yang utuh memiliki rasa percaya diri yang tinggi sehingga kematangan sosialnya juga baik. Sedangkan remaja yang berasal dari keluarga broken home memiliki rasa percaya diri yang rendah sehingga kematangan sosialnya pun tidak baik.

${ }^{29}$ Furqona, "Hubungan Antara Kesadaran Beragama Dan Kematangan Sosial Dengan Agresivitas Remaja (Santri) Pondok Pesantren Modern Islam Assalaam Surakarta.”

${ }^{30}$ L.S. Marwa, "Kematangan Sosial Pada Mahasiswa Merantau Di IAIN Surakarta Social Maturity Of Foreign Student At IAIN Surakarta," Academia 4, no. 1 (2020): 1-16. 


\section{REFERENSI}

Anwar, Anwar. "Paradigma Sosialisasi Dan Kontribusinya Terhadap Pengembangan Jiwa Beragama Anak.” KOMUNIDA : MEDIA KOMUNIKASI DAN DAKWAH, 2018. https://doi.org/10.35905/komunida.v8i2.631.

Creswell, John W. Qualitative Inquiry and Research Design. Qualitative Inquiry and Research Design, 2013.

Elisabet, Hurlock. Psikologi Perkembangan Suatu Pendekatan Sepanjang Rentang Hidup. Erlangga, 2010.

Furqona, R. "Hubungan Antara Kesadaran Beragama Dan Kematangan Sosial Dengan Agresivitas Remaja (Santri) Pondok Pesantren Modern Islam Assalaam Surakarta.” Jurnal Ilmiah Psikologi Pendidikan Dan Perkembangan 1, no. 1 (2009): 51-62.

Ghofiniyah, E. \& Setiowati, E.A. "Hubungan Antara Kematangan Emosi Dan Keterampilan Sosial Dengan Penyesuaian Diri Pada Santri Pondok Pesantren Daar Al Furqon Kudus." Proyeksi 12, no. 1 (2017): 1-16.

Hartanti, A. "Perbedaan Tingkat Kematangan Sosial Anak Berdasarkan Urutan Kelahiran Pada Siswa TK Islam Terpadu Kelas B Mutiara Hati Sawojajar Malang." Universitas Islam Negeri Maulana Malik Ibrahim Malang, 2010.

Lisardika, Adinni Vibrananda, and Heru Astikasari Setya Murti. "Perbedaan Kematangan Sosial Anak Usia Dini Ditinjau Dari Keikutsertaan Di Taman Penitipan Anak (TPA)." Psikologika: Jurnal Pemikiran Dan Penelitian Psikologi, 2017. https://doi.org/10.20885/psikologika.vol22.iss2.art7.

Magdalena, Hasan Almutahar, and Antonia Sasap Abao. "Pola Pengasuhan Anak Yatim Terlantar Dan Kurang Mampu Di Panti Asuhan Bunda Pengharapan (PABP) Di Kecamatan Sungai Raya Kabupaten Kubu Raya.” Jurnal PMIS-Utab, 2014.

Maibang, S.W. "Peran Panti Asuhan Putri 'Aisyiyah Dalam Mengembangkan Kreativitas Anak." Universitas Asislam Negeri Sumatera Utara, 2017.

Marcelyna, C. "Studi Kasus Karakteristik Kematangan SosialPada Anak Cerebral PalsyDitinjau Dari VSMS(Vineland Social Maturity Scale)." Ristekdik (Jurnal Bimbingan Dan Konseling) 5, no. 2 (2020): 146-54.

Marwa, L.S. "Kematangan Sosial Pada Mahasiswa Merantau Di IAIN Surakarta Social Maturity Of Foreign Student At IAIN Surakarta." Academia 4, no. 1 (2020): 1-16.

Mohammad Asrori. "Psikologi Remaja: Perkembangan Peserta Didik. Jakarta: PT Bumi Aksara. Hlm.” Psikologi Remaja Perkembangan Peserta Didik, 2017.

Monks, F.J., Knoers, A.M.P., \& Haditono, S.R. Psikologi Perkembangan: Pengantar Dalam Berbagai Bagiannya. Yogyakarta: Gajah Mada University Press, 2006.

Pratiwi, U., Lusmilasari, L. \& Hartini, S. "Hubungan Antara Kematangan Sosial Dengan Kemandirian Pemenuhan Aktivitas Dasar Penyandang Retardasi Mental.” JIK 03, no. 03 (2008): 202-9.

Pratiwi, U., L. Lusmilasari, and S. Hartini. "Hubungan Antara Kematangan Sosial Dengan Kemandirian Pemenuhan Aktivitas Dasar Penyandang Retardasi Mental." Jurnal Ilmu Keperawatan UGM, 2008.

Rahmat, Pupu Saeful. "Penelitian Kualitatif.” Journal Equilibrium, 2009.

Ramanda, P. \& Khairat, I. "Perbedaan Kematangan Sosial Siswa Yang Berasal Dari Sekolah 
Homogen Dan Sekolah Heterogen.” Jurnal Kajian Bimbingan Dan Konseling 2, no. 4 (2017): 148-156.

Santrock, John W. Perkembangan Remaja (11th Ed.). Perkembangan Remaja (11th Ed.), 2007.

Wahyudhi, Qudsi Iftikar, Tulus Winarsunu, and Sofa Amalia. "Kematangan Sosial Dan Problem Focused Coping Pada Laki-Laki Usia Dewasa Awal." Jurnal Ilmiah Psikologi Terapan, 2019. https://doi.org/10.22219/jipt.v7i1.7835.

Widyawati, Sri, and Martha Kurnia Asih. "KEMATANGAN SOSIAL DITINJAU DARI KOMUNIKASI DIADIK IBU DAN ANAK PADA PESERTA DIDIK TK/PAUD.” Jurnal Dinamika Sosial Budaya, 2017. https://doi.org/10.26623/jdsb.v18i2.578. 